\title{
PETTICOATS AND PREJUDICE: WOMEN AND LAW IN NINETEENTH CENTURY CANADA by Constance Backhouse (Toronto: Women's Press, 1991)
}

Petticoats and Prejudice is a book of legal history written by a feminist woman in an attempt to tell the stories of women and their struggles with the law in an era when misogyny was both prevalent and articulate. The book is divided into four parts. The first part is entitled "The Regulation of Marriage, Courtship and Sexual Violence" and contains three chapters. Chapter one is on "The Ceremony of Marriage" and deals with the legal validity of First Nations marriages as well as the requirement in Quebec of a father's consent to his children's marriage. The second chapter is on "Seduction" and deals with fathers' legal entitlement to damages from men who seduced their daughters. The third chapter is on rape. The second part of the book is entitled "Fertility" and is divided into two chapters one on infanticide and the other on abortion. The third part is entitled "The Nineteenth-Century Family." The first chapter of the third part is entitled "Divorce," but in substance this chapter deals primarily with domestic violence and women's rights to property. The second chapter of the third part is on child custody. The fourth part of the book deals with "Women's Work in the Paid Labour Force." Here the first chapter is on prostitution. The second chapter is on "Protective Labour Legislation," and the third is entitled: "Lawyering: Clara Brett Martin, Canada's First Woman Lawyer."

The difficulty of the project undertaken by Backhouse in Petticoats and Prejudice can only be fully understood in light of the complexity of the relationship between story and teller, history and historian, news and reporter, law and law maker. She undertakes to reconstruct the stories of women and their interaction with the law in nineteenth century Canada from a women's perspective. However, her raw materials are necessarily disproportionately composed of stories of women constructed by male journalist, lawyers, judges and politicians that reflect nineteenth century male interpretation of women's actions and characters.' Essentially, the project of the book is to view the evidence from a feminist perspective and forge feminist interpretations of actions and characters.

This reconstruction is symbolically encapsulated by Backhouse in the task of rehabilitating and reconstituting the notion of the heroine. She seeks to recognize the women she writes about as heroines. But she also seeks to forge, through the telling of their stories, a new understanding of the idea of a heroine as someone quite different from either a female version of the violent conqueror or the femme fatale of gothic romance. ${ }^{2}$ In attempting to create this new paradigm, however, Backhouse is not always successful in detoxifying her portraiture of woman.

In reinterpreting the stories of women, Backhouse clearly recognizes that sexism is not the only aspect of the nineteenth century Canadian sensibility that needs to be overcome. There is also racism, cultural chauvinism, classism and fear of disability to be taken into consideration when attempting to identify the underlying prejudices that fuelled both the substance of the stories and the way they were told. Backhouse takes care to ensure that 
her rendering is sensitive to the existence of these other aspects of nineteenth century bigotry. However, her concern to display her sensitivity sometimes leads her to partake of sexist stereotypes about women to ensure against any interpretation that she may have participated in the construction of racist, classist, or ablist stereotypes.

\section{SEXIST STEREOTYPE AND THE CREATION OF A NEW NARRATIVE OF HISTORY}

An interesting example of this is found in the portrait Backhouse paints of Julia Woolrich. While already married to Susanne Pas-de-nom, a Cree woman, ${ }^{3}$ William Connolly married Julia Woolrich, an upper-class, white woman from Montreal. Woolrich and Connolly were married in a Roman Catholic ceremony. "William Connolly was a prominent fur trader and factor of the Hudson's Bay Company. Connolly and Susanne Pas-de-nom had been married in 1803 in Riviere-aux-Rats in a Cree ceremony. ${ }^{5}$ The two had lived together as husband and wife for thirty years and had seven children together. ${ }^{6}$ In 1832, Connolly suddenly and unilaterally ended his marriage with Susanne Pas-de-nom and married Julia Woolrich. After the deaths of both Connolly and Pas-de-nom, John Connolly, one of the sons of Pas-de-nom and Connolly, challenged Connolly's will which left his estate to Julia Woolrich and the two children of the marriage of Woolrich and Connolly. The validity of the will was contingent upon the invalidity of the Cree ceremony. John Connolly was ultimately successful in overturning the will. It is not clear from the text whether Julia Woolrich was alive at the time of the law suit, though opposing counsel is referred to as "the lawyer for Julia Woolrich's children."7

In discussing the personalities involved, Backhouse is willing to cast Woolrich as the stereotypical uppity, high class, city, white woman who was weak but demanding, coddled, selfish, and self-satisfied. In describing her, Backhouse says:

\footnotetext{
Julia Woolrich and William Connolly set up residence in Montreal 'in great style,' but Connolly's last years in the fur trade were not ones of contentment. Julia Woolrich is said to have greatly disliked the travel to the posts. Her health deterioraled and sle yearned for the amenities of the eity, frequently forcing her husband to return to Montreal. One of Connolly's business partners was moved to complain that William Connolly was so dominated that he was "under petticoat govemment." Governor Simpson disapproved of Connolly's frequent absence from the posts, and he was pushed into early retirement. ${ }^{\mathrm{x}}$
}

The paragraph ends with a footnote to the law report. It is hard to imagine the robust adventurer in the initial description of Connolly being hen pecked and "forced" by his new citified wife to unhappily forgo his career. In the next paragraph, Backhouse goes on to say that:

The name is obviously French and not Cree, ibid. at II.

lhid. at 13.

Ihid. at 9.

Ihid. at 12-13.

Ibid. at 16.

Ihid. at 15 . 
...William Connolly seems to have retained his emotional attachment to Susanne Connolly ...on one occasion Susanne Connolly came to visit him at his Montreal home, causing Julia Woolrich great distress."

Again the paragraph ends with a footnote to the law report. What is interesting here, however, is that Backhouse goes on to note in passing that Julia Woolrich financially supported Susanne Pas-de-nom for fourteen years, from the time of William Connolly's death in 1848 until the time of Pas-de-nom's death in $1862 . .^{10}$

Of course, one does not know why she did so. It may have been out of guilt feelings at having participated in Connolly's betrayal of Pas-de-nom: it may have been becausc Connolly asked her to do it or told her to. It may, however, have been very difficult for Woolrich to sustain even a financial connection to a woman she would likely have considered to be her sexual and emotional rival. Perhaps there was some bond between the women. Or perhaps she viewed her continued financial relationship with Pas-de-nom as noblesse oblige - a fulfilment of an obligation to improve the welfare of the barbarians. Whatever the motivation, the act is intriguing and it is evidence of a more complex situation than Backhouse is prepared to delve into or to speculate about. Rather, she endorses the stereotypical portrait of Julia Woolrich as fussy and domineering -presumably painted initially by the male judge who wrote the judgment in Connolly v. Woolrich striking down the will that bequeathed Connolly's estate to Woolrich and her children.

Backhouse seems to be doing this in order to place herself squarely on the side of the claims of Susanne Pas-de-nom and to ensure that she is seen to be recognizing the racism in white culture. Clearly, it was the correct decision to uphold the validity of the Cree marriage. Further, one ought indeed to condemn Julia Woolrich for marrying William Connolly, knowing that he was already married to Susanne Pas-de-nom. I do not think, however, that insinuating a harsh judgment of Woolrich by referring to her dislike of travel and her bossiness with her lover is a clear, fair, or non-sexist way of pointing out her wrongdoing.

Another example of Backhouse's backhanded condemnation of upper-class, white women through sexist insinuation is found in her discussion of the writing of Henriette A. Drolet Forget. Forget wrote on the position of women and marriage in First Nations culture and was clearly racist in her interpretation of that culture. For this she should be openly condemned by feminist historians. Again, however, Backhouse insinuates her condemnation of Forget by harnessing the power of misogyny. Noting that Forget's husband was Lieutenant-Governor and Indian Commissioner, Backhouse goes on to say, "Perhaps it was her husband's latter position that led her to believe she was qualified to speak on such matters."II Again, Forget should be judged harshly for her racism and cultural chauvinism. But, in my view, that judgement should not be articulated in an

4. Ibid.

10. Ibid.

11. Ibid. at 26. 
indirect way by invoking the stereotype of the stupid woman who wrongly and ridiculously assumes she is infused with her husband's power.

\section{JUDGMENTS OF CREDIBILITY IN LAW AND HISTORY}

In analyzing many of the scenarios discussed in Petticoats and Prejudice, the complexity of the interaction between racism and sexism is almost overwhelming. Backhouse seems, at times, to deal with that complexity by creating a hierarchy of credibility that is basically an inversion of the hierarchy that was operating in the minds of nineteenth century judges. Of course, in looking at the legal histories of conflicts between men and women, it is true that a network of prejudices would be operating in the minds of the white, able bodied men sitting in judgment. Indeed, in making decisions about credibility of witnesses and validity of claims, nineteenth century judges may well have been operating on the basis of an unwritten, unspoken hierarchy of prejudice that operated something like a game of fire/rock/paper/scissors - white man beats white woman, upper class white man beats lower class white man, white woman beats First Nations man, white woman beats chinese man, ${ }^{12}$ white woman beats black man, white woman beats disabled man, upper class woman beats lower class woman, chaste woman beats sexually active woman and so on.

That this kind of hierarchy existed, exists, caused and causes all kinds of injustice is beyond dispute. However, in trying to understand how that hierarchy works and how it can be eradicated, it does little good simply to invert and reapply it in a purportedly enlightened reinterpretation of events. It is important to note that these prejudices would have been operating in the minds of judges, but it is just as important to remember that this, on its own, tells us nothing about who was really telling the truth. Again, however, Backhouse operates by way of insinuation rather than direct comment on events. By using insinuation she avoids the task of thorough analysis of the issues. She makes her position known while making it difficult for the reader to pin down where, how and why she got to that position.

An example of this is seen in her discussion of the case of Soy King. Soy King was a fourteen year old Chinese girl. The case concerned an application for habeas corpus brought by Sam Kee who said that he was her adoptive father. Sam Kee was an affluent Chinese merchant living in Victoria. Soy King had run away from Sam Kee's house and had gone to the Rescue Home for Chinese Girls established in Victoria by methodist missionaries. Sam Kee wanted to regain custody of Soy King. Soy King swore an affidavit stating that she wished to remain in the rescue home rather than return to the home of Sam Kee. She also swore an affidavit that Sam Kee had two wives.

Backhouse refers to Sam Kee's bringing the action for habeas corpus as courageous. Her reasons for viewing it as courageous are that the legal system was openly racially

12. A particularly good illustration of this kind of prejudice about credibility is found in the quotation from Supreme Court Justice Montague William Tyrwhitt Drake at page 221, "The Chinese are utterly unacquainted with truth, and it is a universal comment on their evidence that you cannot believe anything they say." 
biased against Chinese people. ${ }^{13}$ The use of the word courageous is interesting in that it is ambiguous as to whether it connotes moral approval. One could say someone is courageous meaning only she has overcome the resistance or disapproval of others or has overcome a fear that would have dissuaded an average person. In saying so, one would not necessarily mean that the person or her actions were right or good. However, in our usual usage of the word, it implies moral correctness and bravery in a good cause rather than a bad one. By using the word courageous, Backhouse insinuates an alliance with Sam Kee without actually arguing for the basis of that alliance.

The evidence available is that Soy King ran away from Sam Kee: she swore an affidavit saying that she wanted to stay in the rescue home. Yet Backhouse continues to describe Soy King as having been silenced and states that Soy King's perspective on the events is unknown. She says;

Soy King's motivation for leaving is not known. Her voice was silenced in the dispute that erupted almost immediately between the Chinese and Methodist communities. ${ }^{14}$

And later:

Soy King's perspective on this at the time of the trial and thereafter, is not known. Whether she had been physically mistreated or sexually exploited by Sam Kee, whether she was rebelling against Sam Kee's future plans for her, or whether she independently sought the religious environment that the Home offered, is not recorded. ${ }^{15}$

In speaking of the courts acceptance of the affidavit evidence of Soy King, Backhouse says:

The evidence may have been true. But the alacrity with which the judge dismissed any suspicions about the veracity of the affidavit is remarkable. ${ }^{16}$

Backhouse down plays the significance of Soy King's affidavit saying she wanted to stay in the rescue home by saying that "she was clearly not of legal age to make her own decision."17 It is very difficult to decern Backhouse's position here. Taking the evidence as it stands, what reasons would we have to think that Soy King would be untruthful either about her desire to stay in the rescue home or her statement that Sam Kee had two wives? In what way could the keepers of the rescue home have influenced or coerced Soy King to run away and then to give false testimony about her desire to stay there or about the issue of whether or not Sam Kee had two wives? It seems to me that Soy King is not silent in this scenario. She ran away and she said that she wanted to stay away, and she gave evidence of something that she must have known would prejudice the court against Sam Kee. In absence of some other reason to disbelieve her testimony and 
to question the strength of the motives for her action in running away, it seems to me that this should be accepted as her position and that she should not be described as silent.

What Backhouse seems to want to say, and indeed what she should say, is that it is wrong for the white male judges to take the custody of Chinese girls away from Chinese men and give it to white methodist missionaries on the basis that Chinese men should not have custody of Chinese girls because - qua Chinese men - they are depraved. This is, of course, true and right, but again it says nothing about whether Soy King wanted to be with Sam Kee or with the missionaries. The best evidence we have to go on in the case of Soy King and Sam Kee seems to be Soy King's actions and her statements. The fact that Sam Kee was Chinese, and was - for that reason - doomed before he ever reached the courthouse, is neither a reason to doubt Soy King or to put Sam Kee on a pedestal in narrating the dispute.

Of course, it might also be argued that it was wrong for the court to consider Sam Kee's polygamy as relevant to the issue of his fitness for custody. This is another interesting issue that the case raises but it calls for an analysis of the practice of polygamy in Chinese culture, whether Chinese women were exploited in that practice, whether a man's sexual or economic exploitation of people other than the child who is the subject of the custody dispute is relevant to a decision about custody, whether the courts ought to have adopted a position of cultural relativism with respect to custody issue and so on. No such analysis is forthcoming, and, indeed, Backhouse really only gestures at the question.

Essentially, the case raises the question of our moral assessment of the protective actions of reformers and courts toward Chinese women. If we assume that these people were actually helping Chinese women escape exploitation at the hands of Chinese men, and we assume that they were, at least in part, motivated to do so by racist hostility toward Chinese men, what are we to make of their actions? I think the question is a difficult one, but Backhouse again only insinuates a position on it. Speaking of Reverend Scott Seven Osterhout who condemned the ill-treatment of Chinese girls within Chinese culture, Backhouse writes:

Eager to recognize the degradation of women in another society, Reverend Osterhout was apparently less anxious to explore the abuse of women within his own. ${ }^{\text {I' }}$

A direct analysis of the issues here would, I think, be more helpful. I do not think that it should be beyond us to ask whether nineteenth century Chinese culture was more exploitative of women than white culture. If, Chinese women were to say that it was, the very difficult question of how one ought to view white attempts to use white power to forcibly change Chinese culture in that regard would then arise. How should this use of white male power be viewed by feminists committed to supporting the critiques of white euro-centric power structures made by racial and cultural minorities? Do we want to view it as cultural imperialism and therefore condemn it? Do we want to view these sorts of 
exercises of power as steps in the right direction that can be built upon to expose sexist exploitation in white culture? Are Chinese women the only ones in a position to speak on this subject?

These are difficult questions and they are of continuing practical importance in working out the content and meaning of a commitment to the recognition of difference. Perhaps, given the difficulty of the problem and given the demands of the other aims of the book, Backhouse's use of innuendo is understandable. Nevertheless, it strikes me that some more direct analysis of what is at stake in the stories that she tells is needed. I found the frequency with which she gestures at a moral assessment of her characters rather than stating one and defending it to be frustrating.

Another example of her somewhat mechanical approach to issues of difference is found in her discussion of the divorce of Alberta and Alfred Abell. Alfred Abell was deaf. His wife Alberta was not. Alfred Abell ran a school for the deaf. Alfred Abell had repeatedly assaulted and humiliated Alberta Abell. One of the most egregious examples of Alfred Abell's abuse of Alberta Abell is found in the description of Alberta's attempt to escape from Alfred and his extreme violence. In order to prevent her from escaping, Alfred Abell enlisted five of his male students to help him kidnap her on her way to the train station. The six men dragged her back to Alfred's house. There were numerous witnesses to this brutality. Then, in front of the five students he stripped her of all her clothes except her underwear. He then tried to make up with her by kissing her. When she rejected him he burnt her clothes and locked her in her room. ${ }^{19}$

The court granted a divorce to Alberta Abell, and she and her son Eddie went on to live their lives in the poverty and isolation that was inevitable for a woman fixed with the stigma of divorce and without male financial support. ${ }^{20}$ But in the unfolding of the story there emerges a strange ambivalence in Backhouse's tone. In attempting to recognize the prejudice that Alfred Abell would have faced as a witness and a litigant, she then gestures toward an alliance with Alfred Abell and hints at a query about the veracity of Alberta's evidence even though her earlier discussion points to extensive corroboration of Alberta Abell's allegations. ${ }^{21}$ She says:

...Judge Wetmore found the accommodation of deaf witnesses a "painful and tedious undertaking" under "most trying and annoying circumstances." His ruling contained a series of subtle but negative references to "deaf mutes," which clearly evidenced his impatience with them. Judge Wetmore ruled decisively for Alberta Abell on 6 November. Whether he would have ruled the same way if Alfred Abell had been a hearing person is impossible to ascertain. At the very least, it would have been a more halanced contest.

Wetmore justified his decision on the ground that Alberta Abell's allegations against her husband had been "positively proved." As for Alfred Abell's witnesses, the judge was highly sceptical: "Their 
evidence is charactcrized throughout by such ridiculous extravagance and manifest absurdities as to render it to my mind absolutely incredible."22

Clearly, it is wrong that anyone should lose a case because she is deaf. But Backhouse's ambivalence here is difficult to sort out. What do we want to say about the case if it is true that Alfred Abell's deafness was a sine qua non of Alberta Abell's victory in court? What do we say about this if we believe that Alberta Abell's story was true and justice was on her side? What can Backhouse be meaning when she characterizes this contest as unbalanced? It seems to me that the court's prejudice against Alfred Abell allowed them to see Alfred as well as Alberta as "different" or as "other" and the usual identification of the court with the husband or the man was broken. Having viewed them both as "other" and having an orientation of distance from both parties the court was then able to respond appropriately to the violence of the husband. So, the court responded correctly in the circumstances but only because they did not see Alfred able as a part of the club that they were, perhaps even unconsciously, committed to protecting.

Does this make the contest between the husband and the wife unbalanced and weighted in favour of the wife? Does it require us to be more suspicious and more severe in our assessment of Alberta Abell than we would if her husband were a hearing person? I don't think that it does. I think that the contest was, ironically, more balanced because of the absence of the strong identification of the judge with the husband - thus freeing the judge to see the violence for what it was. That the courts were blind to violence against women where the interests of men more like them were at stake, does not necessarily mean that the fairness of the trial between Alfred and Alberta Abell was compromised.

The stories of Sam Kee and Alfred Abell should not lead us to try to forge a sympathetic alliance with these men in these contexts. ${ }^{23}$ One very important thing that I think that these stories can show us, however, is that men of power can abhor violence against and exploitation of women when they can distance themselves from the men who commit that violence. The challenge of these stories for us now is to think of ways to broaden men's field of critical vision and then, further, to direct it into the mirror. Men must be taught to see - and recognize the wrong of - violence against women; not just in the actions of men from whom they can distance themselves, but also in the actions of men with whom they identify and in their own actions as well. None of this goes in any

22. Ihid. at 193 [emphasis added].

23. See K. Crenshaw, "Demarginalizing the Intersection of Race and Sex: A Black Feminist Critique of Antidiscrimination Doctrine, Feminist Theory, and Antiracist Politics" in Bartlett \& Kennedy, eds., Feminist Legal Theory: Readings in Law and Gender (Boulder, Westview Press: 1991) at 72. Her discussion of the movie The Colour Purple bears repetition here. "The animating fear behind much of the publicized protest was that by portraying domestic abuse in a Black family. the movie confirmed the negative stereotypes of Black men. The debate over the propriety of presenting such an image on the screen overshadowed the issue of sexism and patriarchy in the Black community. Even though it was sometimes acknowledged that the Black community was not immune from domestic violence and other manifestations of gender subordination, some nevertheless felt that in the absence of positive Black male images in the media, portraying such images merely reinforced racial stereotypes. The struggle against racism seemed to compel the subordination of certain aspects of the Black female experience in order to ensure the security of the larger Black community." 
way toward justifying or apologizing for racial and cultural or ablist bigotry. But, I would argue that we lose the lessons of the victories of Soy King and Alberta Abell by suggesting that they are instances of unfairness to Sam Kee and Alfred Abell.

\section{THE BATTLE LINES DO NOT SHIFT}

One of the very interesting and helpful aspects of the book is the way that it shows us that many of the battle lines of issues of women and the law today were already clearly drawn in the nineteenth century. The book shows us many examples of the use of the rhetoric of public and private to defend the exclusion of women from the "law's circle of protection."24 It shows us how women's poverty, the veneration of motherhood, the hatred and fear of female sexuality, and the exclusion of women from the market influence the issues of abortion, infanticide, and prostitution and domestic violence.

Interestingly, the book also shows us that the shape of today's divisions between feminists were already strongly developing in the nineteenth century. This is shown in the book's description of the debate between Agnes Machar and Carrie Derick. Both of these were concerned with women's position in the labour force. The two women had similar goals but pursued them through vastly different projects. Agnes Machar comes across in the book as prissy and out of touch with the reality of the lives of the working class women whom she hoped to help. She organized evening self-improvement seminars for working women. On the one hand, the point of the seminars seems to have been a good idea: to provide working women with an opportunity for education and enjoyment - "A place... where they could have books or music, or anything else they liked." But the women did not respond well to the idea. ${ }^{25}$ Carrie Derick also sought to help working women. Her efforts met with significantly more enthusiasm. She set up a Working Girl's Club and Lunch Room in Montreal which provided low cost meals and working women attended in droves. ${ }^{26}$

The differences between Carrie Derick and Agnes Machar, however, were not just reflected in their views about the kind of programs that would most benefit working women. The two women also had vastly different attitudes about how one ought to go about securing better working conditions for women in the work place. Carrie Derick was a successful research scientist with an international reputation. Though clearly not a hard hearted woman, she seemed to have a great deal of faith in a hard nosed approach to life. She thought that it was prohibitively dangerous for women to argue for and obtain protective legislation in the area of labour relations. To do so, she thought, would be to obtain advantages for women that would lead employers to stop hiring women altogether and would, therefore, further disadvantage women in the work force. Thus, she was a strong opponent of the legislative reforms that Agnes Machar was fighting for. ${ }^{27}$ 
Agnes Machar had the better of the argument. She pointed out that men and women were already rigidly segregated in the work force and, therefore, that men and women were not actively competing for the same jobs in any event. Further, she felt that the jobs which women held would not be acceptable to men even if employers were inclined to offer them to men particularly not if they were offered to them at the rate of pay given to women. Thus, it would continue to be cheaper and more efficient for employers to hire and exploit a class of female and child workers who were too disempowered to do anything about their situations. This argument was particularly cogent considering that the legislative reforms were never directed toward improving women's wages but rather to improving their hours and their physical conditions. Everyone seems to have viewed the possibility of legislation requiring equal pay for work of equal value to have been beyond the pale. As long as that remained the case, it would be preferable for employers to hire women in low paying female specific jobs whether or not they were subject to other requirements in respect of their hours or their safety. ${ }^{28}$

Derick's concern for the competitiveness of women seems, then, to have been misguided if one assumed that factors affecting women's wages would remain constant. Derick was, however, apparently driven in her views by her acceptance of social/economic Darwinism and thought, therefore, that protective measures of any kind were

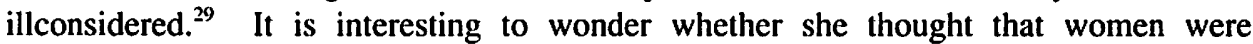
ultimately "fitter" than men and would eventually emerge as the victors in a free market or whether she thought that women should be forced to sink or swim in the market and if they could not swim that they did not belong there. Her own spectacular success in her field would seem to suggest that she would believe that a woman who was tough enough and smart enough could get along in a man's world without any special help in doing so. ${ }^{30}$ So she may have been motivated by Thatcheresque self-glorification to believe that other women, if they thought they were entitled to a better lot in the world, ought simply to be more like her. She may, on the other hand, have been reacting to the way in which Agnes Machar used arguments about women's physical inferiority to support her arguments in favour of protective legislation. ${ }^{31}$

The conflict between the two women is fascinating and resonates through women's discussions today about their entrance and position in the work force. Do special measures to accommodate women's needs help them in the long run or do they simply provide another reason in the minds of employers to look askance at the hiring and promotion of women? If, for example, we get a requirement that employers provide paid maternity leave for women employees, does this act as a barrier to employers hiring women in the first place? Certainly, there are women today who feel that this is true and

2x. Ihid. at 283-84.

29. $\quad$ lid. at 287.

36. Backhouse notes that: "Her rescarch took her to Harvard, the University of Berlin, the University of Munich, the University of Bonn, and the Royal College of Science in London, England," ibid. at 281. Ibid. at 286, Machar spoke of women's lesser physical stamina as a reason for enacting protective legislation. 
who feel that their security in the job market is significantly threatened by such measures. ${ }^{32}$ Others feel that the accommodation of the differences of women in the workplace and the recognition of the obligation to stop foisting all the economic burden of child rearing on to women is the only way to the achievement of any meaningful notion of gender equality. Similarly, the controversy continues around the question of whether affirmative action programs are ineffective because they are seen as an indication that women are of lesser capacity than men and are, therefore, in need of special help in competing against men. A fly on the wall in any faculty meeting on the issue of equity in hiring will inevitably hear a discussion of whether attempts to even out power imbalances between groups does or does not imply some acceptance of a premise of the inferiority of the disempowered group. So, the debate between Agnes Machar and Carrie Derick continues.

Another important question that is raised by the debate between the two women is the recurring question in feminist discussion of whether it matters how women get what women want. Does the way that we argue for reform and for recognition of our difference alter the quality of the victory of obtaining that recognition? Agnes Machar and others like her argued for improved working conditions for women partly on the basis of women's inferior stamina but also partly on the basis of the threat to women's fertility and essential mothering capacities that were posed by the harshness of the work environment. ${ }^{33}$ To take another example from the book, if lower class women who committed infanticide in desperation were dealt with leniently by the courts, does it matter that the reason for the court's mercy was its lack of concern for lower class illegitimate children $?^{34}$ If women were protected by the law of seduction from sexual exploitation, does it matter that the reason for the existence of the law was the protection of the interest of the father in the sexual property he held in his daughter or that the law defines a woman's consent as either irrelevant or impossible? ? $^{35}$

Should feminists only make arguments that are consistent with women's integrity and their theoretical conceptions of themselves or should they make arguments that do not necessarily reflect their reality but that do advance their cause and are likely to appeal to those who have the power to make the decisions? Should women argue for increased rights to abortion using the rhetoric of individual autonomy, choice and privacy when this rhetoric is offensive to many other feminist ideas and goals. Should women be pleased or disappointed when courts recognize the emotional harm done to a woman who sees her

See for example W.W. Williams, "The Equality Crisis: Some Reflections on Culture, Courts and Feminism" in Bartletl \& Kennedy. Feminist Legal Theory, supra, note 23 at 26 where Williams says: "My own feeling is that, for all its problems. the equality approach is the better one. The special treatment one has great costs. First, as discussed above, is the reality that conceptualizing pregnancy as a special case permits unfavourable as well as favourable treatment of pregnancy. Our history provides us with too many examples of the former to allow us to be sanguine about the wisdom of urging special treatment."

33. Backhouse at 265 and 286.

4. Ihid. at 135-36.

35. Ibid. at 51 . 
child killed in an accident by invoking the stereotype of the selfless mother goddess? $?^{36}$ Should we insist that we are given our due on the basis of a full appreciation of who we are and why we are entitled to the things we demand? Or should we get what we want by whatever means are available to us including the exploitation of stereotypes about our value?

Again, Backhouse veils her position on this issue, but it would seem that she is somewhat judgmental of the women who enlisted sexist stereotype to push for reform. I would argue that, given the desperation of women's position in society at that time, we should forgive them for being machiavellian, and maybe we should even forgive them for believing in the arguments that they made. This is not to say that we should follow in their footsteps. I would argue that we should not. But, I would argue that if we endorse the goals of nineteenth century women, we should be slow to cast aspersions on their use of arguments that would be sellable to nineteenth century men in power.

Another aspect of the book that resonates with today's struggles is found in the discussion of academic violence in the context of Clara Brett Martin's entrance into law school. It is interesting to see the nineteenth century justification of academic violence as a preservation of the natural qualities of womanhood. Women's intellectual development was seen as unnatural and harmful to their reproductive capacity. ${ }^{37}$ Women who entered into the academy were met with hostility, ridicule and disdain. Classmates and professors emphasised the sexual aspects of cases in an effort to make Clara Brett Martin uncomfortable. ${ }^{38}$ Male students' ridicule of females were an amusing means of creating a hostile environment for women and attempting to force them out by creating a climate in which it would be impossible for a woman to function effectively. Backhouse describes the bar admission celebration of Clara Brett Martin's class:

The graduating class staged its annual year-end "Mock Trial" to celebrate its call to the bar. That year women were marked out for particular ridicule. One man decked himself out as a woman of remarkable girth, complete with voluminous dress, cape, and shawl. The final touch was the hat an ostentatious, feathered, bejewelled monstrosity. "She" was paraded into the courtroom, and against the backdrop of Osgoode Hall's stately brick arches and stained glass window, prosecuted lter case as plaintiff in a civil trial to the uproarious amusement of the mixed audience that filled the hall to capacity.

Universities still struggle with the identical phenomenon and attempts to render women ineffectual in their participation in the institution. ${ }^{39}$

M. Chamallas \& L. Kerber, "Women, Mothers and the Law of Fright" (1990) 88 Mich. L. Rev. 814. Backhouse at 297.

lbid. at 313.

See B. Feldthusen, "The Gender Wars: 'Where the Boys Are"' (1990) 4 C.J.W.L. 66; D. Harris, "Keeping Women in Our Place" (1991) 11(4) Can. Women Studies 37; S. McIntyre, "Promethea Unbound: A Feminist Perspective on Law in the University" (1989) 38 U.N.B.L.J. 157; S. Vella, "Feminist Refugees" (1990) 11(1) Jurisfemme 9. 


\title{
IV. CONCLUSION
}

Backhouse's book is a welcome attempt to uncover the stories of women and the law in the nineteenth century. In doing so, she reveals to us the clarity with which the battle lines of women's struggles have been drawn for a considerable period of time. Her stories bring us closer to an understanding of our ideological legacy as feminists. They also give us insight into the pitfalls of women of privilege speaking for dispossessed women. Many of the stories, however, call for further analysis and Backhouse's use of insinuation is often both disappointing and frustrating. I invariably found myself wishing that she would be more forthright in her moral assessment of the stories she narrates. While I admired her attempt to free her narratives from classism, ablism and racism, I wished that she could have freed her analysis from the fear of being labelled racist or classist or ablist.

\author{
Annalise Acorn \\ Assistant Professor \\ Faculty of Law \\ University of Alberta
}

